\title{
论文
}

\section{新疆艾比湖小叶桦湿地空气花粉散布特征及其 与气象因子的关系}

陈立欣 ${ }^{1,2}$, 张芸 $^{1,2,3^{*}}$, 孔昭宸 ${ }^{1}$

1. 中国科学院植物研究所植被与环境变化国家重点实验室, 北京 100093 ;

2. 中国科学院大学生命科学学院, 北京 100049 ;

3. 河北地质大学地球科学学院, 石家庄 050031

* 通讯作者, E-mail: zhangygl@ibcas.ac.cn

收稿日期: 2020-10-12; 收修改稿日期: 2021-04-14; 接受日期: 2021-06-10; 网络版发表日期: 2021-08-09 国家自然科学基金项目(批准号: 41971121和41572331)、中国科学院战略性先导科技专项(A类)项目(编号: XDA19050103)和中国地质科学院 水文地质环境地质研究所基本科研业务费项目(编号: SK202012)资助

摘要空气花粉能够用于指示植被和气候状况. 本研究利用Pearson相关分析和拉格朗日混合单粒子轨道(HYSPLIT)模型对中国西北地区的艾比湖小叶桦湿地2012年9月到2015年8月的空气花粉散布特征及其对气象因子的 响应进行研究分析. 结果表明, 2012年9月到2013年8月, 花期时较高的温度和适宜的降水有助于桦木花粉的产量 增加, 再加上被外来气流从天山地区带来的云杉属花粉, 导致这一年的乔木植物花粉浓度达三年来最高值; 2013 年9月到2014年8月的总花粉浓度为三年中的最高值, 可能是由于高温低降水有利于草本植物花粉的散播, 并且该 年夏秋季有大量来自艾比湖西南部和中亚地区的外来花粉; 2014年9月到2015年8月,夏秋季当时的气象条件不利 于㢣科、䒾属等旱生植物花粉散布, 且源自哈萨克丘陵的外来气流携带的花粉量较少, 导致该年的总花粉浓度最 低. 气象因子和外来气流都会对空气花粉的浓度造成显著影响, 该研究结果可为桦木属花粉的散布特征研究、该 区域的古环境重建以及湿地保护工作提供重要的参考资料.

关键词 空气花粉, 气象因子, 相关分析, 桦木属花粉, 艾比湖湿地

\section{1 引言}

1970 2015年，全球天然湿地平均减少了 $35 \%$ (Ramsar Convention, 2018; Darrah等, 2019). 湿地消亡 速度的增加将导致生态系统退化和生物多样性减少, 这迫切需要施行更有效的保护措施(Erwin, 2009; 田润 炜等, 2017; Mao等, 2018). 在干旱-半干旱地区如中国
新疆，湿地在维持脆弱的生态系统方面扮演着重要的 角色(蔡新斌等，2015). 随着经济、社会的不断发展， 新疆湿地的消亡越来越严重. 新疆艾比湖桦木属湿地 是干旱-半干旱地区具代表性的宝贵湿地，由于近几十 年艾比湖的严重萎缩, 该湿地中小叶桦(Betula microphylla) 的数量仅剩328株(李玉梅, 2019; Wang等, 2019). 了解桦木属植物的演化历史和影响其种群数量 
变化的因素，有助于更好地保护该物种和整个湿地生 态系统. 除了人类活动，气候变化在天然湿地的退化 中也有着无可争议的作用. 研究气象和气候因子对该 树种花粉的影响，对解决平衡社会发展和生态保护之 间关系的问题至关重要.

现代花粉数据通常用于解释地层花粉数以及重建 过去的植被和气候环境(Zhang等, 2010; 赵楠楠等, 2019). 作为现代花粉研究的重要组成, 与表土花粉相 比，空气花粉的监测记录不仅可以辨别其对气候变化 的即时响应(Latorre, 1999; Crimi等, 2004), 而且可以 了解更长时间尺度上物种和植被的变化(Cariñanos等, 2004). 欧洲与中国的相关研究都表明，每年的花粉高 峰期与当地植被的花期相对应(Meiffren，1988; Rousseau等, 2006; Xu等, 2012). 之前的许多研究也指出, 气 象因子尤其是温度、降雨量和风速与空气花粉浓度之 间存在相关性(Caramiello等，1994; Bortenschlager和 Bortenschlager, 2005; Rahman等, 2019). 欧洲的空气 花粉研究指出, 较高的温度和适量的降雨有利于花粉 的散播(Jato等, 2002; Ribeiro等, 2006; Stjepanović等, 2015), 并且风向也对空气花粉组合有显著的影响 (Rojo等, 2015). 在中国，气象因子影响着空气花粉的 季节变化, 不同季节呈现出不同的花粉组合特点(蒋素 雪, 2010; 吕素青等, 2012). 在中国的北部和东部地区 如北京、石家庄和南京(何海娟等，2001; 张军等, 2009; 李英等, 2014; Fang等, 2018), 春季和秋季有两 个高峰期, 分别以乔木和草本植物花粉为主. 而在中国 南方的大部分地区，仅在3 5月有一个高峰期(Rahman 等, 2019). 在中国西北干旱地区, 强风天气极大地影响 了以旱生草本和灌木植物花粉为主的空气花粉组合 (Zhao等, 2021). 此外, 对海洋上空空气花粉散布的研 究表明, 其传播距离主要受风的影响(徐家声, 1994; 戴 璐和翁成郁, 2010).

了解空气花粉散布与大气环境之间的关系，可以 更好地解释现代花粉组合和源区植被的变化特征. 然 而，许多地区仍缺乏基本数据. 对艾比湖地区的研究 大多集中在地层花粉和表土花粉上(李玉梅，2019; 王 力, 2019; Zhang和Kong, 2019), 对空气花粉组合方面 的研究却较少. 因此, 本研究通过对艾比湖小叶桦湿地 连续3年(2012年9月至 2015 年 8 月)大气花粉数据进行 监测，可通过联系该花粉浓度变化与气象因子的关系， 从而明确其年际散布特征与源区植被的关系. 采用统
计学方法和后向轨迹分析方法对该地区空气花粉组合 进行分析，其中针对华木属、云杉属、蒿属和䕌科花 粉分别进行详细的讨论. 这些结果将有助于分析植被 对气候变化的响应关系进而更好地解释地层花粉 记录.

\section{2 材料和方法}

\section{1 研究区概况}

艾比湖是新疆最大的咸水湖，位于精河县北部 $\left(44^{\circ} 31^{\prime} \sim 45^{\circ} 09^{\prime} \mathrm{N}, 82^{\circ} 33^{\prime} \sim 83^{\circ} 53^{\prime} \mathrm{E}\right.$ ), 平均海拔 $189 \mathrm{~m}$ (图 1). 该地区属温带大陆性干旱气候, 蒸发量远大于降水 量. 年平均气温 $7.8^{\circ} \mathrm{C}$, 年平均降水量 $95 \mathrm{~mm}$. 来自阿拉 山口的风导致该地区每年有 165 天的风速超过 $17 \mathrm{~m} \mathrm{~s}^{-1}$. 垂直带植被自上而下(即按海拔递减顺序)可分为六个 区：高山草甸(>2929m)、亚高山草甸(2714 2314m)、 森林(2210 1809m)、草原(2826 1013m)、荒漠草原 (2521 217m) 和荒漠(388 210m)(王力, 2019).

由于受到人为干扰和气候变化, 艾比湖萎缩逐渐 加剧，其植被面积锐减约 60\%(Mu等，2002； Bao等， 2006). 艾比湖桦属湿地是湖区东南部的一片小沼泽 地, 该地主要生长小叶桦和典型的水生植物如沼泽蕨 (Thelypteris palustris)和芦苇. 200多年前，这个地区被 称为桦树林子; 而现今桦木的数量逐渐减少到 328 株 (李玉梅, 2019). 该地区的强风天气导致的沙尘暴会造 成生物多样性的严重退化和经济损失. 因此, 需要尽快 恢复艾比湖湿地的环境并保护桦木林.

\section{2 大气花粉和气象数据}

在艾比湖国家湿地自然保护区的小叶桦湿地内设

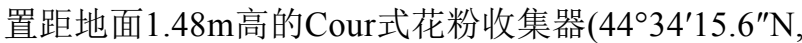
$\left.83^{\circ} 44^{\prime} 43.4^{\prime \prime} \mathrm{E}\right)(\mathrm{Cour}, 1974)$ 以监测大气花粉浓度. 样品 于2012年9月开始采集，至2015年8月完成. 每年的9月 至下一年的 8 月定义为一年. 使用的滤网面积为 $20 \mathrm{~cm} \times 20 \mathrm{~cm}$ ，春季和夏季时每周更换一次，秋季和冬 季时每两周更换一次. 在 36 个月期间共收集了 97 个 样本.

采用标准实验方法处理样品, 用浓硫酸 $\left(\mathrm{H}_{2} \mathrm{SO}_{4}\right)$ 分 解滤网; 并使用氢氟酸 $(\mathrm{HF}) 、 20 \%$ 盐酸 $(\mathrm{HCl})$ 和 $10 \%$ 氢 氧化钠 $(\mathrm{NaOH})$ 去除碳酸盐、硅酸盐和多余的有机成 分. 之后在超声波中进行过笁, 并使用9:1混合溶液(醋 


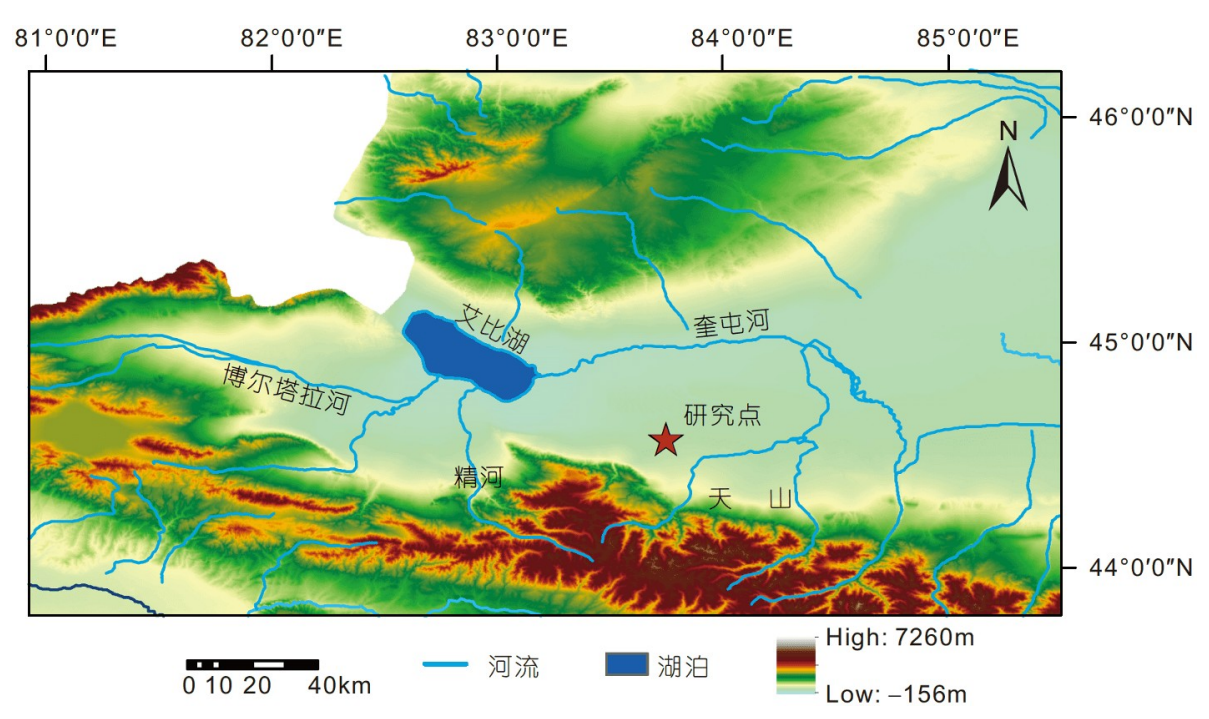

图 1 研究区和监测点(红色五星)的地理位置

酸酐: 98\%硫酸=9:1)去除样品中的纤维素. 在Olympus CX31显微镜下对样品进行鉴定和计数, 每个样品使用 四个盖玻片，最后计算花粉百分比和浓度. Pearson相 关性分析在R 3.6.2中完成.

日均气象数据来自精河附近的一个气象站, 与研 究时段对应, 包括平均温度、日降水量、平均风速、 日照时间和相对湿度.

\section{3 统计方法}

利用Cour(1974)提出的体积法对空气花粉数据进 行处理.

每个滤网收集的花粉量计算如下:

$Q=(S / N) \times N_{0} \times 10 d \times 2$,

式中, $Q$ 是花粉粒的总和, $S$ 表示鉴定的数量, $N$ 表示鉴 定的总行数, $N_{0}$ 表示鉴定的总行数/盖玻片数, $d$ 表示甘 油滴数.

空气花粉百分比的计算如下所示:

$W=n / N \times 100 \%$,

式中, $W$ 是花粉的百分比, $n$ 是已鉴定分类群的数量, $N$ 是鉴定的花粉总数.

花粉浓度 $\left(\right.$ 粒 $\left.\mathrm{m}^{-3}\right)$ 计算如下:

$C=Q /\left(V \times T \times S_{0}\right)$,

式中, $C$ 是花粉浓度, $Q$ 是花粉总数, $V$ 是平均风速, $T$ 是 收集时间, $S_{0}$ 是滤网的面积大小.

\section{4 后向轨迹模拟分析}

为探究研究区内大气花粉的来源和运输途径, 利 用美国国家海洋大气管理局(NOAA)和美国大气研究 实验室(ARL)开发的拉格朗日混合单粒子轨道模型 (HYSPLIT)进行后向轨迹模拟分析. 基于全球数据同 化系统(GDAS, http://www.arl.noaa.gov)(Draxler和 Hess，1998)的气象资料，利用垂直运动场模拟不同海 拔地区的大气物质散布和沉积. HYSPLIT模型操作简 单, 但在高度上有限制, 与气团的实际轨迹有 $20 \%$ 的误 差(Stohl，1988). 然而，依据统计计算方法(Stein等, 2015; Rolph等, 2017), 该模型已大大减少其不确定性, 是自1997年以来研究气团运输轨迹和散布的有效、合 适的工具. 它还可用于研究大气花粉的源区和运输途 径(Pasken和Pietrowicz，2005; Lu等，2010; 方伊曼, 2015; Luo等, 2018; Zhao等, 2019; Lü等, 2020).

在本研究中, 对2012 2015年不同花粉高峰期(春 季、夏季和秋季), 以 $6 h$ 为间隔, 进行后向48h(Plaza等, 2016; Celenk, 2019)的后向轨迹进行模拟分析, 并且选 择距地面 $50 、 500$ 和 $1000 \mathrm{~m}$ 三个高度, 确保能够囊括气 团从地表到大气边界的轨迹(Stein等, 2015). 其他许多 相关研究也在大气花粉轨迹分析中选择这些高度 $(\mathrm{Lu}$ 等, 2010; Dimitriou和Kassomenos, 2014). 500和 $1000 \mathrm{~m}$ 高度的花粉分别属于适中距离和远距离运输(Zhao等, 2019；Lü等，2020；Stępalska等，2020)，而最低高度 $(50 \mathrm{~m})$ 则是根据样品采集器的高度选择. 


\section{3 结果}

\section{1 大气花粉组合特征}

从2012年8月至2015年9月收集的97个花粉样品中 共鉴定出 57 科属植物的花粉. 其中, 草本植物花粉共计 33 种, 乔木和灌木植物计 22 种, 另外 2 种为水生植物. 各 年大气花粉组合中均以草本植物花粉为主，如蒿属 (Artemisia)、藜科(Chenopodiaceae)、菊科(Compositae)、禾本科(Poaceae)、石竹科(Caryophyllaceae)和豆 科(Leguminosae)花粉; 乔木植物花粉则主要由桦木属 (Betula)、云杉属(Picea)、松属(Pinus) 和榆属(Ulmus) 花粉组成. 图2为主要花粉类型的百分比图. 自2012年9 月至2013年8月，草本植物花粉约占总数的 $77 \%$ ，乔木 植物花粉为 $20 \%$, 灌木植物花粉仅占 $3 \% .2013$ 年9月至 2014年8月, 草本、灌木和乔木植物花粉百分含量分别 为 $86 \% 、 4 \%$ 和 $9 \% .2014$ 年9月至 2015 年 8 月, 乔木植物 花粉由 $9 \%$ 增至 $13 \%$, 草本和灌木植物花粉分别为 $83 \%$ 和 $4 \%$. 在连续三年收集的大气花粉样品中，花粉百分 含量的增加是主要是由于优势类群含量的变化. 桦木 属花粉从2012年9月至 2013 年 8 月的 $17 \%$ 降至 2013 年 9 月至2014年 8 月的 $6 \%$ ，在2014年9月至2015年8月增加 至10\%．蒿属花粉从第一年的10\%增加至2013年9月至 2014年 8 月之间的 $22 \%$ ，在第三年下降至 $11 \%$. 萩科花 粉第一年为 $59 \%$ 而后两年下降到 $54 \%$. 此外还收集到 了一些水生植物花粉, 例如香蒲 (Typha) 和黑三棱 (Sparganium), 但花粉样品中没有观察到蕨类孢子.

\section{2 空气花粉浓度}

三年来每年的花粉浓度变化数据如图 3 和 4 所示. 在2012年9月至2013年8月, 4 月 $\left(1.41\right.$ 粒 $\left.\mathrm{m}^{-3}\right)$ 和 8 月 $(1.24$ 粒 $\mathrm{m}^{-3}$ ) 出现两个峰值, 分别以乔木植物花粉和草本植 物花粉为主. 花粉总浓度为 16.83 粒 $\mathrm{m}^{-3}$, 其中桦木属花 粉为 6.45 粒 $\mathrm{m}^{-3}$, 云杉属花粉为 0.023 粒 $\mathrm{m}^{-3}$, 蒿属花粉 为 0.88 粒 $\mathrm{m}^{-3}$, 菉科花粉为 7.98 粒 $\mathrm{m}^{-3}$, 禾本科花粉为 0.40 粒 $\mathrm{m}^{-3}$. 2013年9月至2014年8月，分别在 8 月 (1.39 粒 $\left.\mathrm{m}^{-3}\right)$ 和9月 $\left(1.21\right.$ 粒 $\mathrm{m}^{-3}$ )观察到两个高峰期, 花粉总 浓度增至20.55 粒 $\mathrm{m}^{-3}$, 这主要是由于藜科(12.78 粒 $\left.\mathrm{m}^{-3}\right)$ 和蒿属 $\left(5.08\right.$ 粒 $\left.\mathrm{m}^{-3}\right)$ 花粉含量的增加. 在这一年 中，乔木植物花粉浓度显著下降，尤其是桦木属花粉 $\left(0.71\right.$ 粒 $\left.\mathrm{m}^{-3}\right)$. 从2014年9月到2015年8月，花粉浓度仅 为 3.17 粒 $\mathrm{m}^{-3}$, 只在 10 月出现一个峰值 $\left(0.77\right.$ 粒 $\left.\mathrm{m}^{-3}\right)$, 这
主要是因为几乎所有的花粉类型的浓度减少，特别是 㢣科(从 12.78 粒 $\mathrm{m}^{-3}$ 降至 2.18 粒 $\mathrm{m}^{-3}$ ) 和蒿属(从 5.08 粒 $\mathrm{m}^{-3}$ 降至 0.28 粒 $\mathrm{m}^{-3}$ ) 花粉.

\section{3 气象数据}

气象数据表明，2012年9月至2013年 8 月年均温最 低, 为 $8.49^{\circ} \mathrm{C} ; 2013$ 年9月至 2014 年 8 月年均温升高并达 最高，为 $9.35^{\circ} \mathrm{C}$; 在 2014 年 9 月至 2015 年 8 月略降至 $9.17^{\circ} \mathrm{C}$ (图5a). 图5b展示了月均温的变化，与年均温的 年际变化趋势类似. 年均风速也在逐年增加, 在 2012 年 9月至2013年8月为 $1.40 \mathrm{~m} \mathrm{~s}^{-1} ， 2013$ 年9月至2014年8月 为 $2.20 \mathrm{~m} \mathrm{~s}^{-1} ， 2014$ 年 9 月至 2015 年 8 月为 $2.49 \mathrm{~m} \mathrm{~s}^{-1}$ (图 5a). 最高月均风速通常出现在 5 月, 而在冬季可见最低 风速(图5c). 图 $5 \mathrm{~d}$ 为每年的月降水量情况. 与温度变化 趋势相反, 年降水量在2012年9月至2013年8月达到了 最大值 $(136.1 \mathrm{~mm})$, 在2013年9月至2014年8月, 下降至 $82.8 \mathrm{~mm}$, 而在最后一年(2014年9月至2015年8月), 年降 水总量增加到了 $116.6 \mathrm{~mm}$ (图5a). 月降水量主要分布在 春季和夏季, 且持续波动(图5d). 根据每年的风向分布, 可以很明显地看到在前两年中, 主要是北风和西北风, 而2014年9月至2015年8月的风主要来自东南部.

\subsection{Pearson相关分析结果}

对三年来不同季节的大气花粉浓度与主要气候因 子进行了Pearson相关分析(表1). 春季的总花粉浓度 $(r=0.910, p<0.05)$ 和桦木属花粉浓度 $(r=0.952, p<0.01)$ 均与降水量有极显著正相关关系. 夏季的总花粉浓度 与相对湿度之间呈显著正相关性 $(r=0.806)$, 云杉属花 粉浓度与风速也具有正相关关系 $(r=0.783)(p<0.05)$. 蒿 属花粉浓度与温度 $(r=-0.890, p<0.01)$ 和降水 $(r=$ $-0.791, p<0.05$ )呈负相关性(表1). 揫科花粉浓度与相 对湿度呈显著正相关 $(r=0.767, p<0.05)$. 在秋季除了花 粉总浓度与温度 $(r=0.887)$ 和日照时间 $(r=0.924)$ 之间具 有显著相关关系外, 只有蒿属花粉的浓度与气象因子 具显著相关关系，其花粉浓度与温度 $(r=0.928)$, 降水 $(r=0.957)$ 和日照时间 $(r=0.902)$ 呈显著正相关，与相对 湿度 $(r=-0.890)$ 为负相关 $(p<0.05)$. 在冬季, 空气花粉 浓度与气象因子之间无显著的相关关系.

\section{5 后向轨迹模拟分析结果}

不同高度的后向模拟传输路径表明，在春季主要 


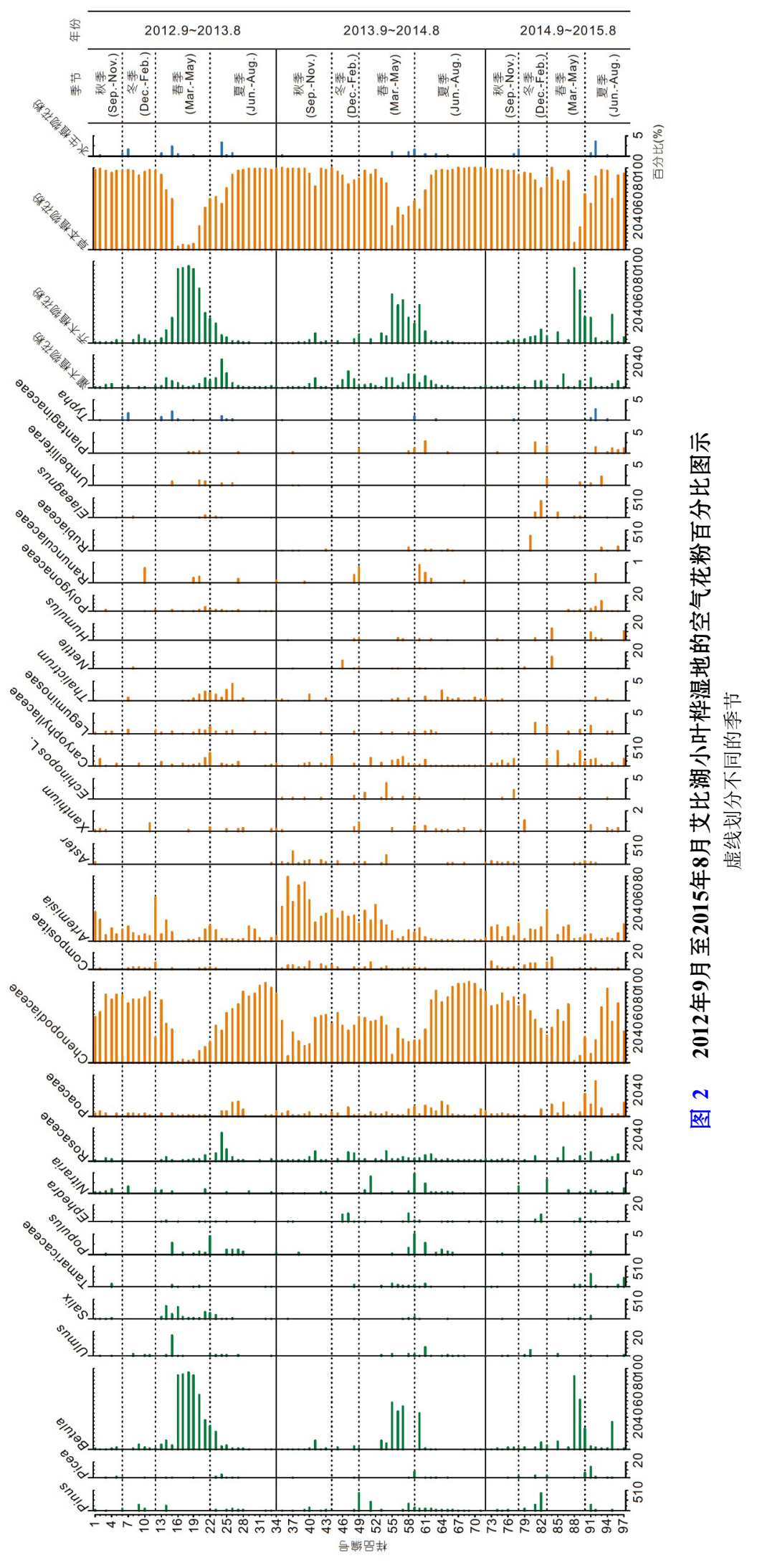


陈立欣等: 新疆艾比湖小叶桦湿地空气花粉散布特征及其与气象因子的关系

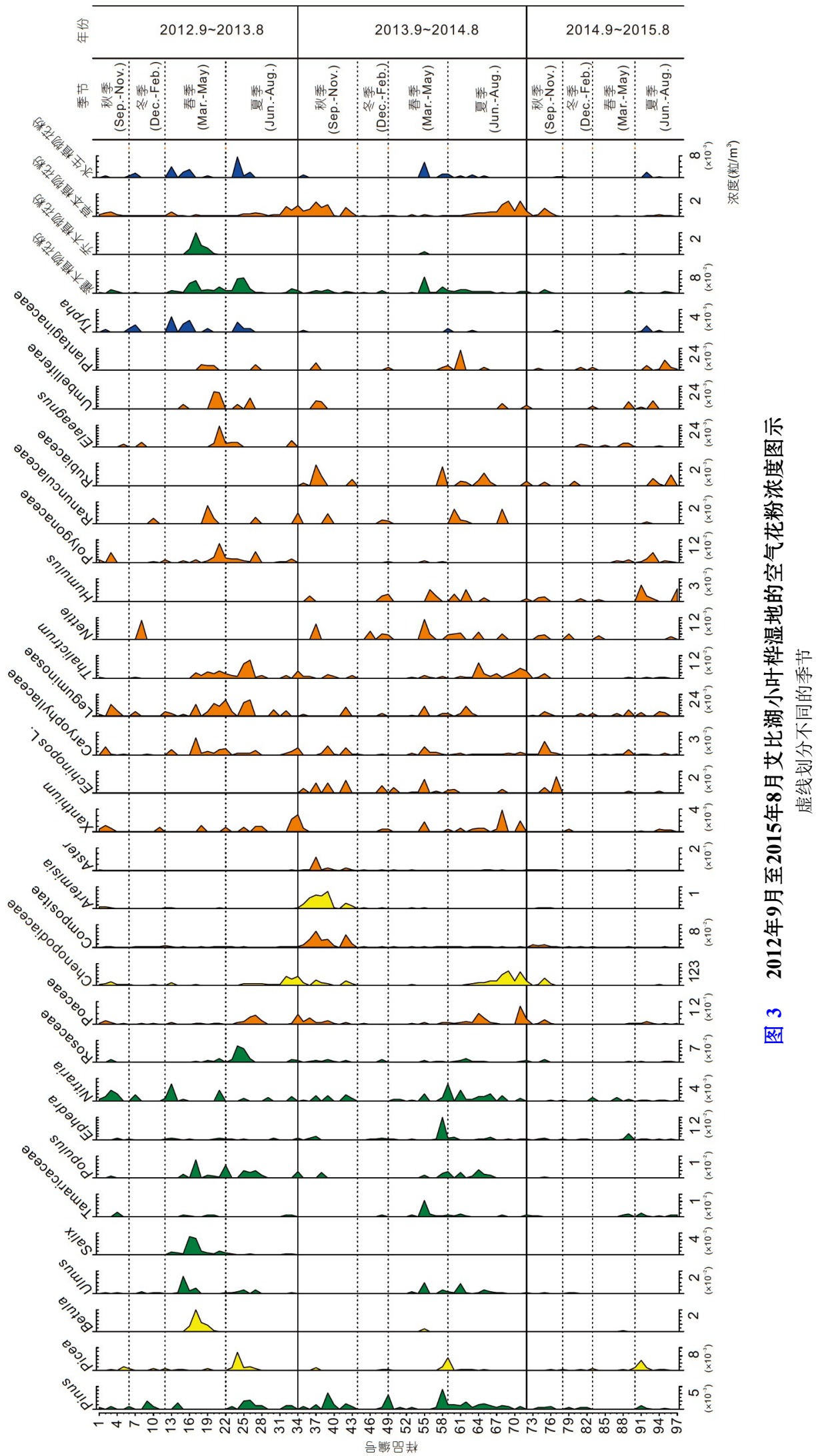




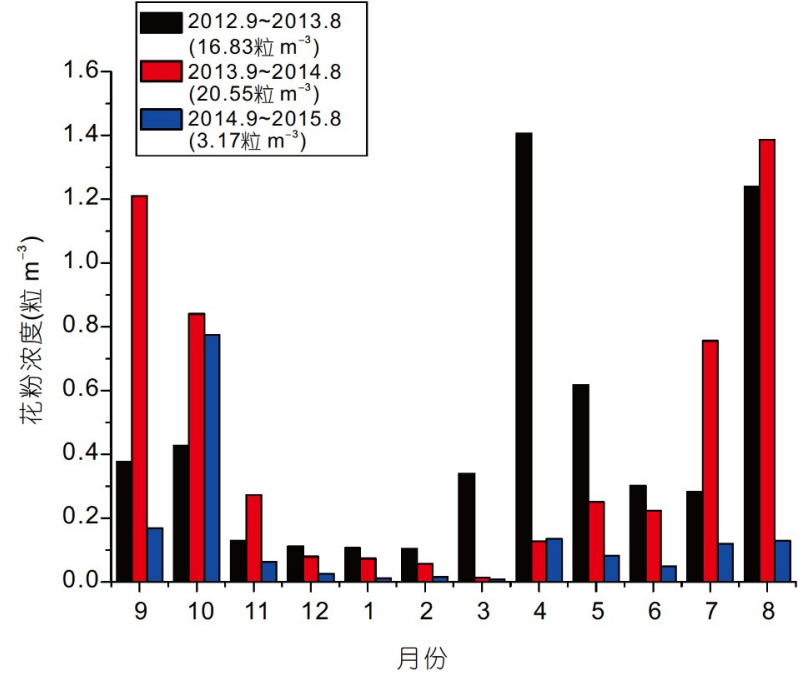

图 42012 年9月至2015年8月艾比湖小叶桦湿地总花粉浓 度变化

是来自中亚东南部和艾比湖湿地西南的荒漠地带或西 天山山脉的气流(图6a 6c). 在前两年的夏季(2012年9 月至2013年8月以及2013年9月至2014年8月)，气流是 来自于艾比湖湿地西南部的荒漠地区(图6d 6e). 2014 年9月至 2015 年 8 月, 50 和 $500 \mathrm{~m}$ 高的西北气流是从哈萨 克丘陵经阿拉山口而来， $1000 \mathrm{~m}$ 处的气流则源于艾比 湖西南部的荒漠和西天山北坡等地区(图6f). 在每年 秋季, 不同高度的气团均是来自西南地区，在2012年9
月至 2013 年 8 月， 50 和 $500 \mathrm{~m}$ 高的气团是来自艾比湖湿 地西南部的荒漠，而 $1000 \mathrm{~m}$ 高的气团是从中亚地区的 荒漠地带而来(图6g); 从2013年9月至2014年8月, 较高 的气团 $(500$ 和 $1000 \mathrm{~m})$ 来自中亚荒漠地区(图6h), 而 $50 \mathrm{~m}$ 主要是从西天山的北坡来的气团(图6i).

\section{4 讨论}

\section{1 空气花粉组合特征及与当地植被的关系}

从艾比湖东南部的小叶华湿地收集到的样品中, 主要是灌木和草本植物花粉, 包括藜科、蒿属、菊 科、禾本科、麻黄属、白刺属和蓄薇科等，表明湿地 外主要分布有荒漠和荒漠草原植被. 空气花粉中高含 量的杨属和柳属花粉主要源于生长在艾比湖森林和灌 木植被中的胡杨林及柳属植物(李玉梅, 2019). 桦木属 花粉则主要来自桦木湿地的优势植物小叶桦, 桦木林 中伴生的水生植物的花粉也出现在本研究的大气花粉 组合中. 依据艾比湖湿地的植被分布情况, 除云杉属花 粉外, 该区域的空气花粉组合能够较好地反映当地的 植被分布. 植被调查显示, 在艾比湖湿地并没有云杉 林的生长. 李玉梅(2019)的研究中指出, 在天山西部别 珍套山和阿拉套山交界处的博尔塔拉河流域的沟谷中 有云杉林生长, 云杉属花粉可能源于该区. 而且, 由于 云杉属花粉具双气囊、易于被远距离搬运的特点(潘

表 1 大气花粉浓度与各气候因子的Pearson相关分析结果 ${ }^{a)}$

\begin{tabular}{|c|c|c|c|c|c|c|c|c|c|c|}
\hline & \multicolumn{5}{|c|}{ 春季 } & \multicolumn{5}{|c|}{ 夏季 } \\
\hline & 均温 & 总降水 & 均风速 & 日照时长 & 相对湿度 & 均温 & 总降水 & 均风速 & 日照时长 & 相对湿度 \\
\hline 总花粉浓度 & 0.244 & $0.910^{*}$ & 0.381 & 0.234 & -0.251 & 0.096 & -0.354 & -0.542 & -0.476 & $0.806^{*}$ \\
\hline 桦木属 & 0.302 & $0.952 * *$ & 0.413 & 0.296 & -0.290 & -0.067 & 0.021 & 0.577 & -0.339 & -0.559 \\
\hline 云杉属 & 0.534 & -0.175 & 0.479 & 0.458 & -0.421 & -0.127 & 0.179 & $0.783^{*}$ & -0.211 & -0.737 \\
\hline 藜科 & -0.765 & -0.399 & -0.607 & -0.776 & 0.636 & 0.213 & -0.245 & -0.489 & -0.373 & $0.767^{*}$ \\
\hline \multirow[t]{3}{*}{ 蒿属 } & -0.072 & -0.753 & -0.054 & -0.112 & -0.101 & $-0.890 * *$ & $-0.791 *$ & -0.665 & -0.391 & 0.256 \\
\hline & \multicolumn{5}{|c|}{ 秋季 } & \multicolumn{5}{|c|}{ 冬季 } \\
\hline & 均温 & 总降水 & 均风速 & 日照时长 & 相对湿度 & 均温 & 总降水 & 均风速 & 日照时长 & 相对湿度 \\
\hline 总花粉浓度 & $0.887^{*}$ & 0.759 & 0.392 & $0.924 *$ & -0.860 & 0.715 & 0.731 & -0.006 & -0.291 & 0.485 \\
\hline 桦木属 & 0.214 & -0.317 & -0.660 & 0.287 & -0.349 & -0.238 & 0.307 & -0.366 & -0.713 & 0.634 \\
\hline 云杉属 & -0.624 & -0.383 & -0.064 & -0.622 & 0.517 & 0.100 & 0.657 & 0.557 & 0.441 & -0.381 \\
\hline 藜科 & 0.706 & 0.472 & 0.085 & 0.791 & -0.693 & 0.500 & 0.585 & -0.420 & -0.570 & 0.718 \\
\hline 蒿属 & $0.928 *$ & $0.957^{*}$ & 0.688 & $0.902^{*}$ & $-0.890^{*}$ & 0.804 & 0.496 & 0.724 & 0.429 & -0.254 \\
\hline
\end{tabular}

a) $*$, 在 0.05 水平上显著相关(双侧); $* *$, 在 0.01 水平上显著相关(双侧) 

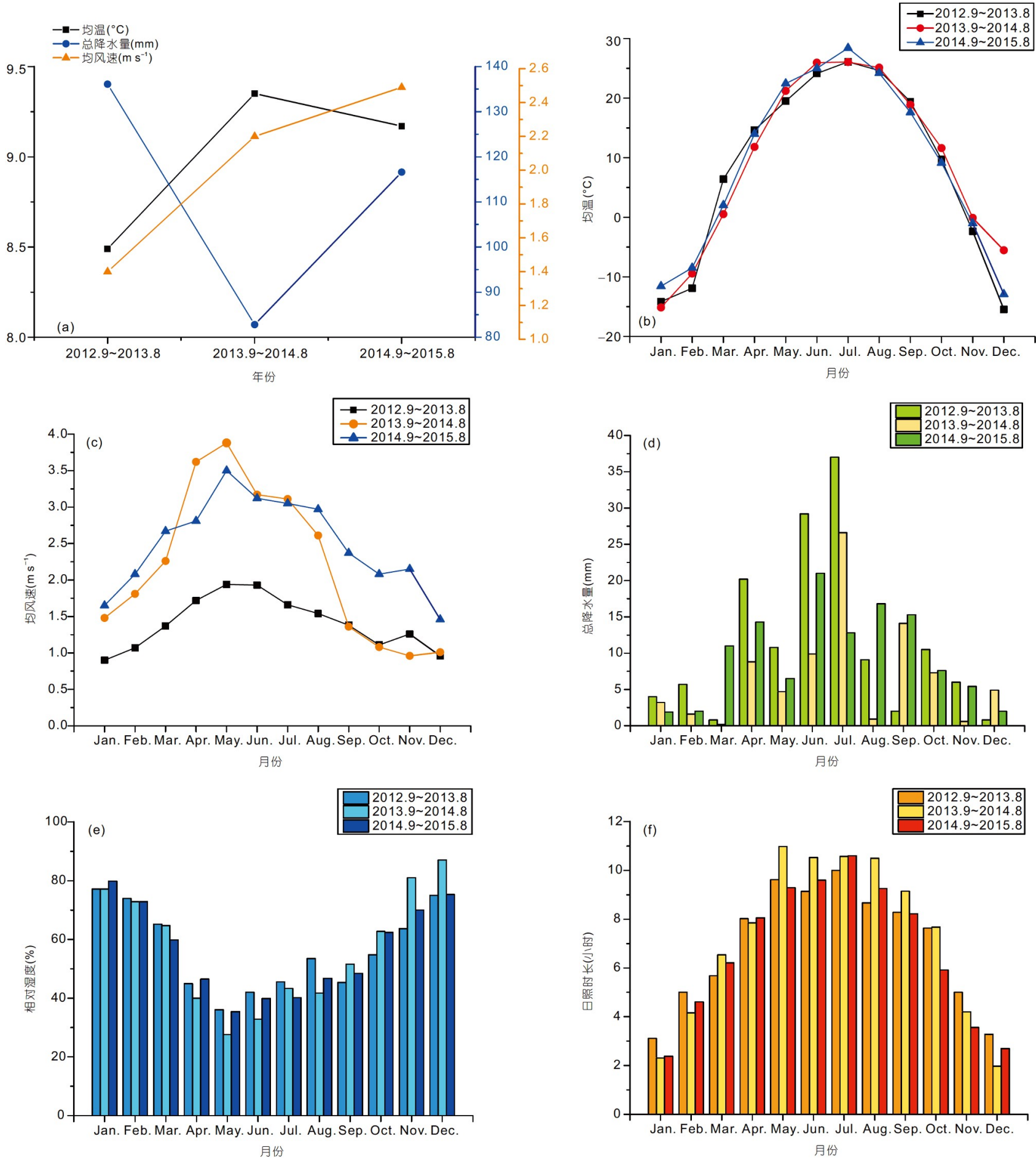

图 52012 年9月至 2015 年8月艾比湖气象数据

(a) 年均温、年降水量和年均风速; (b) 月均温; (c) 月均风速; (d) 月总降水量; (e) 月均相对湿度; (f) 月均日照时长

燕芳等, 2011), 即使是在没有云杉林生长的地区, 全年 甚至是冬季也都会有云杉属花粉的记录. 因此, 大气花
粉组合不仅能指示当地的植被情况，也能反映远距离 搬运的花粉类型. 


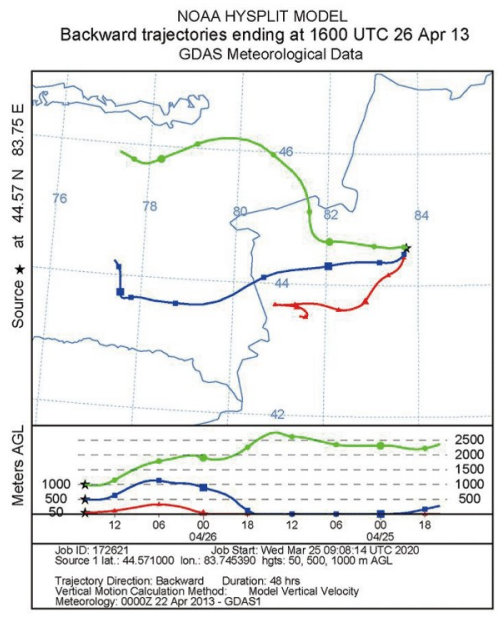

(a)

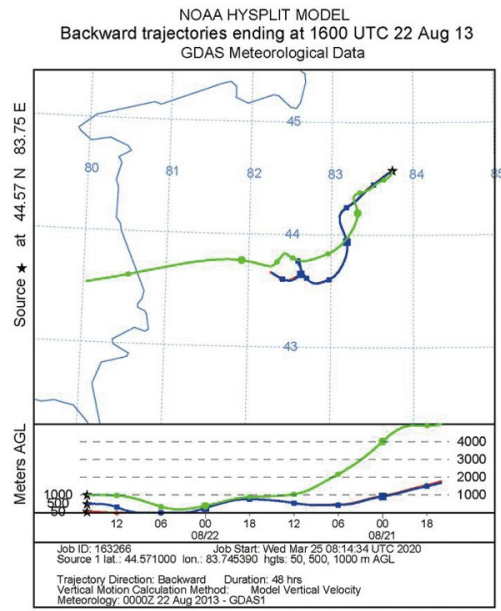

(d)

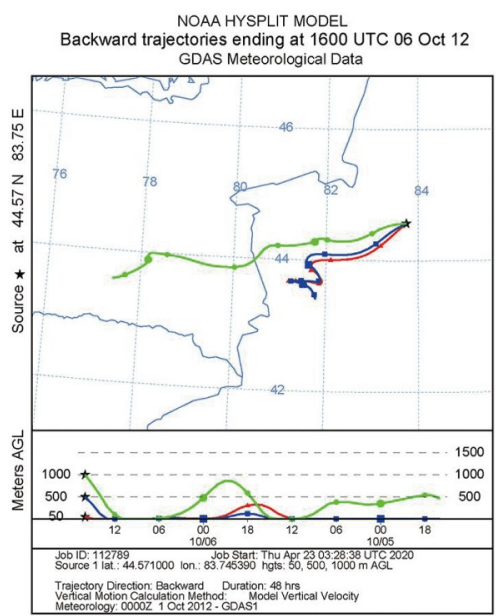

(g)

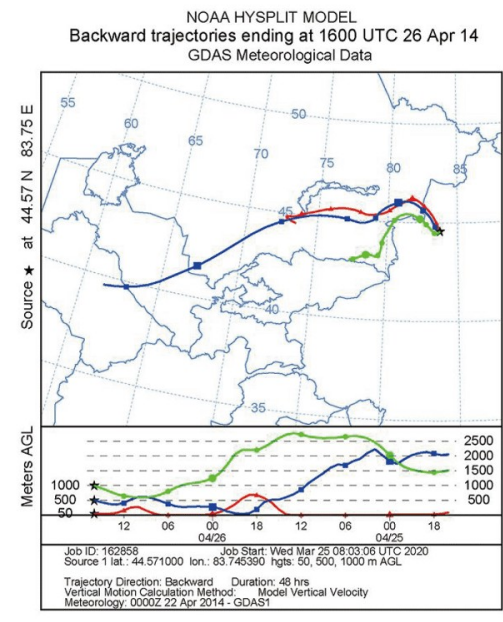

(b)

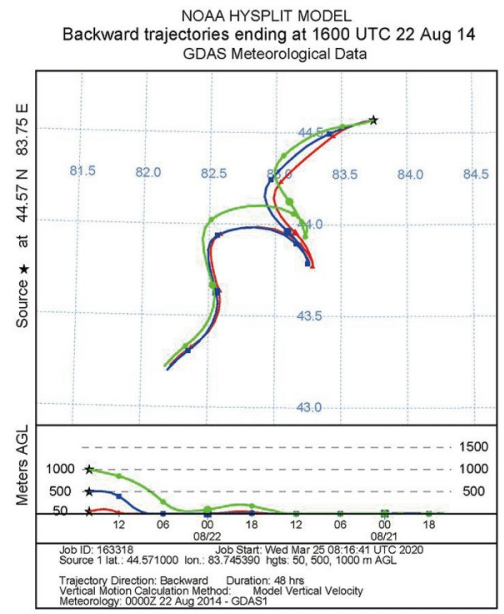

(e)

NOAA HYSPLIT MODEL

NOAA HYSPLIT MODEL
Backward trajectories ending at 1600 UTC 06 Oct 13

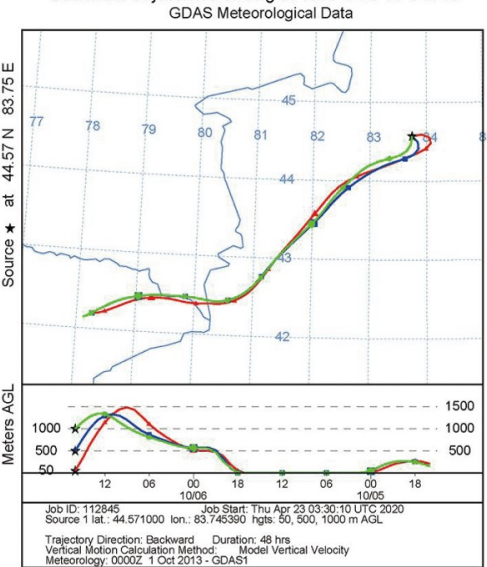

(h)

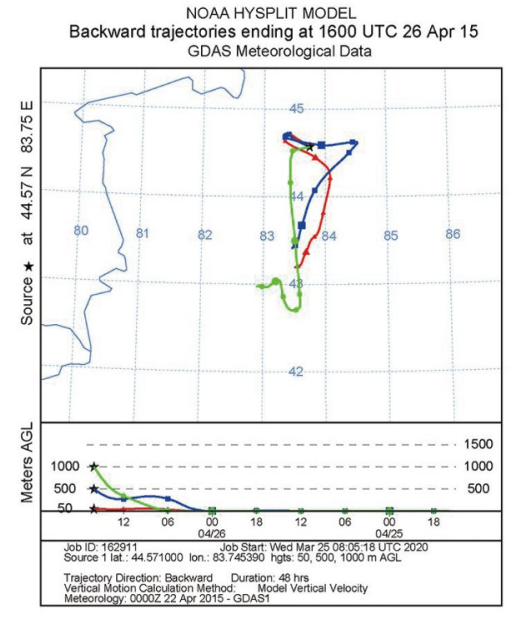

(c)

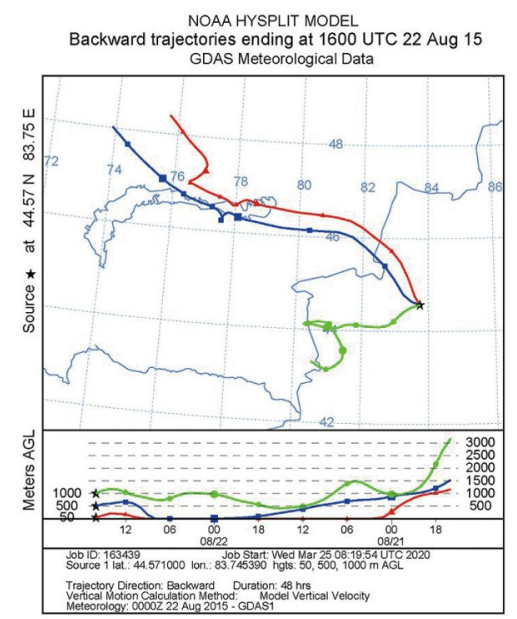

(f)

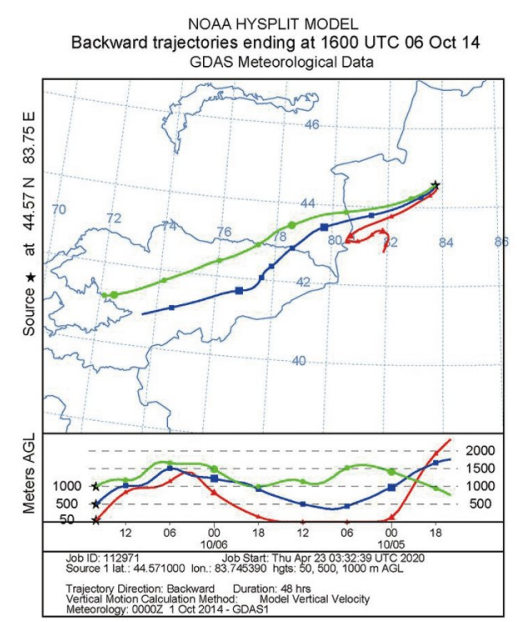

(i)

图 6 基于GDAS气候数据的 $48 \mathrm{~h}$ 内后向轨迹模拟分析结果

(a) (c) 春季(2013、2014和2015年的4月26日)；(d) (f) 夏季(2013、2014和2015年的8月22日)；(g) (i) 秋季(2012、2013和2014年的10月6日); $50 \mathrm{~m}$ 为红色线; $500 \mathrm{~m}$ 为蓝色线; $1000 \mathrm{~m}$ 为绿色线; 星号代表研究点; 更多信息详见https://windfarm/manati.orbit.nesdis.noaa.gov 
根据在研究区所做的植被调查，桦木林下生长有

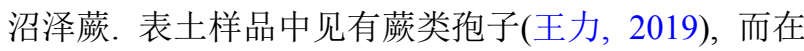
空气花粉样品中却并未见该孢子的存在. 造成这一现 象的主要原因之一是蒴类植物在湿地和森林植被中多 生长在林下, 孢子散布的高度受限, 因此在地层样品中 对当地植被具重要的指示作用(Nagalingum等，2002; Tang等，2013); 此外，颗类孢子更易沉降在附近的表 土中, 而不易被风远距离搬运. 对空气花粉和表土花粉 组合的对比结果表明，蒝类狍子在表土花粉中的存在 可以反映当地有该植物的分布, 尤其是在暖湿环境下.

\section{2 大气花粉组合与气象因子间关系的综合分析}

图7展示了研究区2012年9月到2015年8月总空气 花粉浓度与各气象因子每周的变化，表明每年空气花 粉的高峰期均与植物花期相对应，同时受到气象条件 的影响又表示出不同的变化趋势. 该区空气花粉的散 布主要与温度、降水、风速和风向密切相关，这与前 人的研究结果一致(刘克利等, 2009; Sabit等, 2016; 张 雨辰等，2018). 因该区的地形有利于多发的大风携带 花粉远距离搬运至此，并对当地花粉的散布有一定的 不利影响(Lü等, 2020). 本研究利用外来气团后向轨迹 模型展示了外来花粉可能的来源和运输轨迹. 艾比湖 位于阿拉山口，来自大西洋的西风气流主要经过该通 道，造成该区大风天气频发. 远距离而来的气团可以 经由阿拉山口或者源于西天山南坡的气流能够携带外 来花粉到达艾比湖，尤其4 8月的高风速(图5c)更利于 外来花粉的远距离搬运. 图8a表明较高浓度的桦木属 花粉具明显的温度和降水区间, 即浓度高于 0.1 粒 $\mathrm{m}^{-3}$ 时, 对应的温度范围为 $11 \sim 26^{\circ} \mathrm{C}$, 降水量为 $4 \sim 21 \mathrm{~mm}$, 且 该花粉最适宜的温度是 $19^{\circ} \mathrm{C}$; 这一温度和降水区间涵 盖了最适合桦木属植物开花的气候区间，表明多数收 集的桦木属花粉是来自于生长在艾比湖湿地的小叶 桦．在图8b中，云杉属花粉几乎分布在整个气候区间 中，从散点图中无法得知该花粉最适宜的气候区间， 进一步表明这一花粉是来自于研究区外的植被. Lü等 (2020)指出，根据青藏高原的实际植被情况，即可辨别 出春季时收集到的松科和桦木属花粉属于外来花粉. 此外, 在巴里坤湖的研究也证明, 大部分的旱生植物花 粉如藜科和蒿属都属于外来花粉, 并且因其能指示区 域植被, 可用于跟踪中亚地区的外来气流输入过程 (Zhao等, 2021). 蒿属花粉分布的温度和降水范围也较 广(图8c), 同样难以确定该属植物生长所对应的气候 区间，因此在本研究区，多数蒿属花粉也被认为是源 于研究区外并具超代表性, 与前人的结果一致(许英勤 等, 1996; 桑艳礼等, 2008). 图8d中较高浓度的莍科花 粉 $\left(>0.1\right.$ 粒 $\left.\mathrm{m}^{-3}\right)$ 也处于较宽的气候区间内, 无法得知该 科植物生长的最适气候区间，表明藜科花粉也具有超 代表性, 且多数源于研究区外. 因此, 大气花粉组合中 的外来花粉类型可通过研究区实际植被分布、花期中 异常的浓度高峰期(Monroy-Colín等, 2020)以及适宜气 候区间来确定.

从2012年9月到2013年8月，总花粉浓度在春夏季 达到最高, 春季与乔木植物花期对应, 夏季与草本植 物花期对应; 这与中国北方如北京、石家庄，以及东 部地区如南京等的大气花粉季节分布特征相似(何海 娟等，2001; 张军等，2009; 李英等，2014; Fang等, 2018). 乔木植物花粉浓度与春季花期时温度、降水的 关系要比年均温、年降水更加密切, 能够反映生长季 时的天气条件(毛利米, 2008). 本研究中, 春季时桦木 属花粉与总降水量呈极显著正相关 $(r=0.952, p<0.01)$, 并且较高浓度的桦木属花粉所对应的降水范围为 2 15mm(图8a), 表明在桦木属植物花期时, 温度和降 水的增加会促进桦木属花粉产量的增多. 春季艾比湖 地区主要是北风和西北风，经过博尔塔拉河流域的高 空气团和来自天山的低空气团(图6a)带来一些乔木植 物花粉, 这可能是这一年春季乔木植物花粉浓度达到 三年中最高值的原因之一. 草本植物花粉主要是僽科 和蒿属, 多来自于研究区外植被, 来自艾比湖湿地西 南部荒漠地区的气流可能是造成这一年草本植物花粉 浓度相对较高的原因(图6). 然而，这一年最高的总降 水量、最低年均温和风速也在一定程度上亦会影响草 本植物花粉的散布.

2013年9月到2014年8月时，乔木植物花粉浓度显 著降低, 而草本植物花粉浓度却达三年中的最高值, 造成这一年中两次的花粉浓度高峰期均是以草本植物 花粉为主. 根据艾比湖地区的植被分布以及植物的物 候变化, 这一年空气花粉季节散布特征的变化应是受 到气象因子的影响. 花期时干热的环境有利于草本植 物如僽科和蒿属花粉的产出和散播. 在这一年中蒿属 花粉显著的高峰期可能是与该年高温、低降水和高风 速的气候条件有关(图7). 与蒿属花粉受到的影响相同, 较高产量的藜科花粉也是受到干旱温暖的气候条件的 

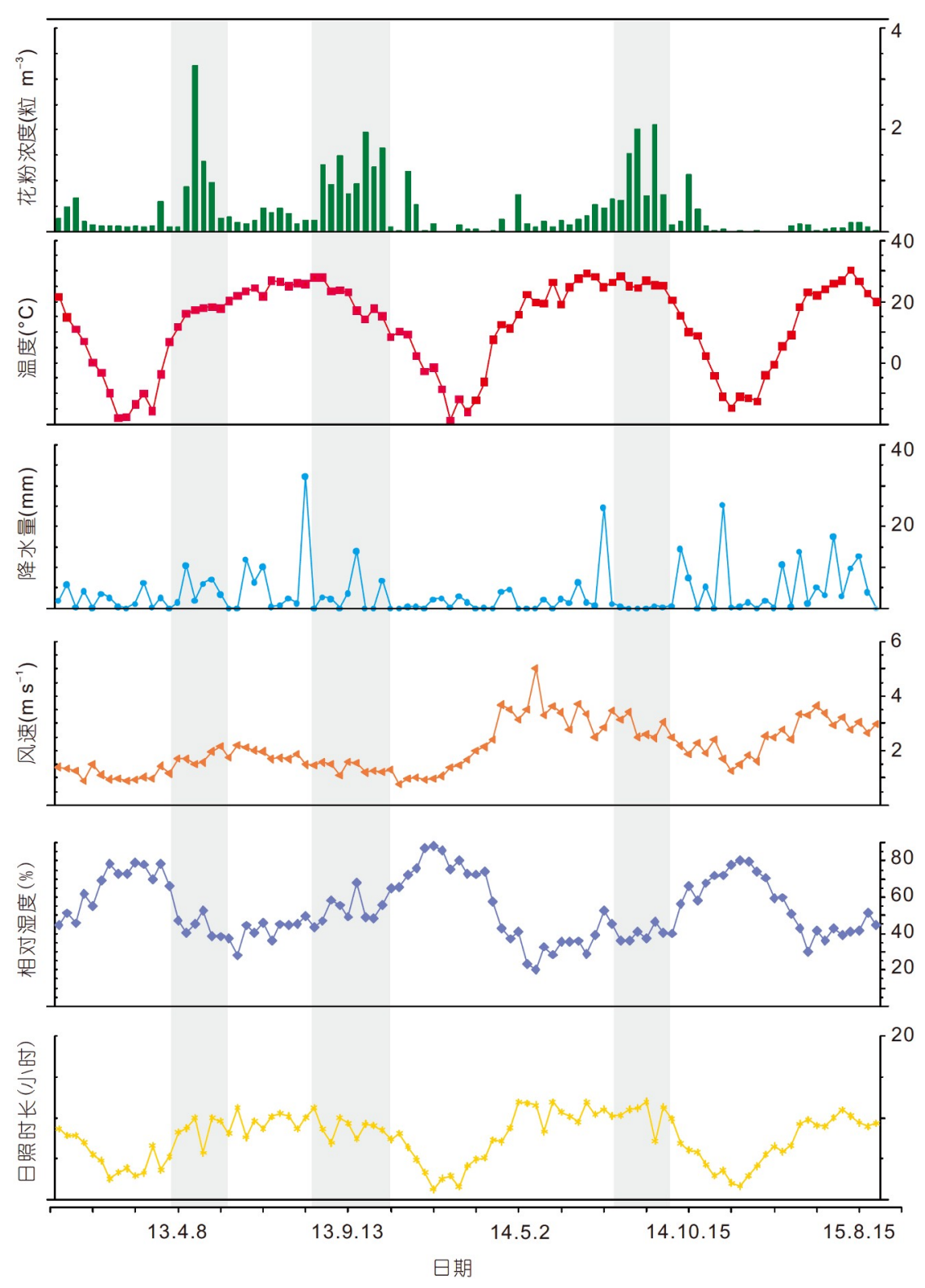

图 72012 年9月至 2015 年 8 月艾比湖小叶桦湿地大气花粉浓度及各气象因子的周变化 花粉浓度高峰期用灰色区域标出

影响. 此外，该年的空气花粉组合中也可能有外来花 粉，特别是具低沉降速度 $\left(<0.015 \mathrm{~m} \mathrm{~s}^{-1}\right)$ 的藜科和蒿属 花粉，很容易被风远距离搬运(Zhang等，2016)。夏季 时，外来花粉主要由来自艾比湖西南部荒漠地区的气 流搬运而来(图6e); 秋季时, 气流携带源于中亚荒漠地 区的旱生植物的花粉(图6h). 乔木植物花粉浓度的降 低主要表现在桦木属花粉量的减少，除了受到不利的 气候条件和物候变化特征的影响外(Spieksma等,
1995)，该年乔木植物花粉和草本植物花粉浓度的变化 也受到春季外来花粉的影响，来自哈萨克斯坦南部荒 漠的气流(图6b)携带更多的草本植物花粉，而乔木植 物花粉则较少.

在2014年9月到2015年8月的花粉季节中持续的高 降水量会对空气花粉的散布造成负面影响, 致使这一 年的总花粉浓度处于三年中的最低值. 研究表明, 由 于水合作用，较高或持续的降水会减少空气中花粉的 

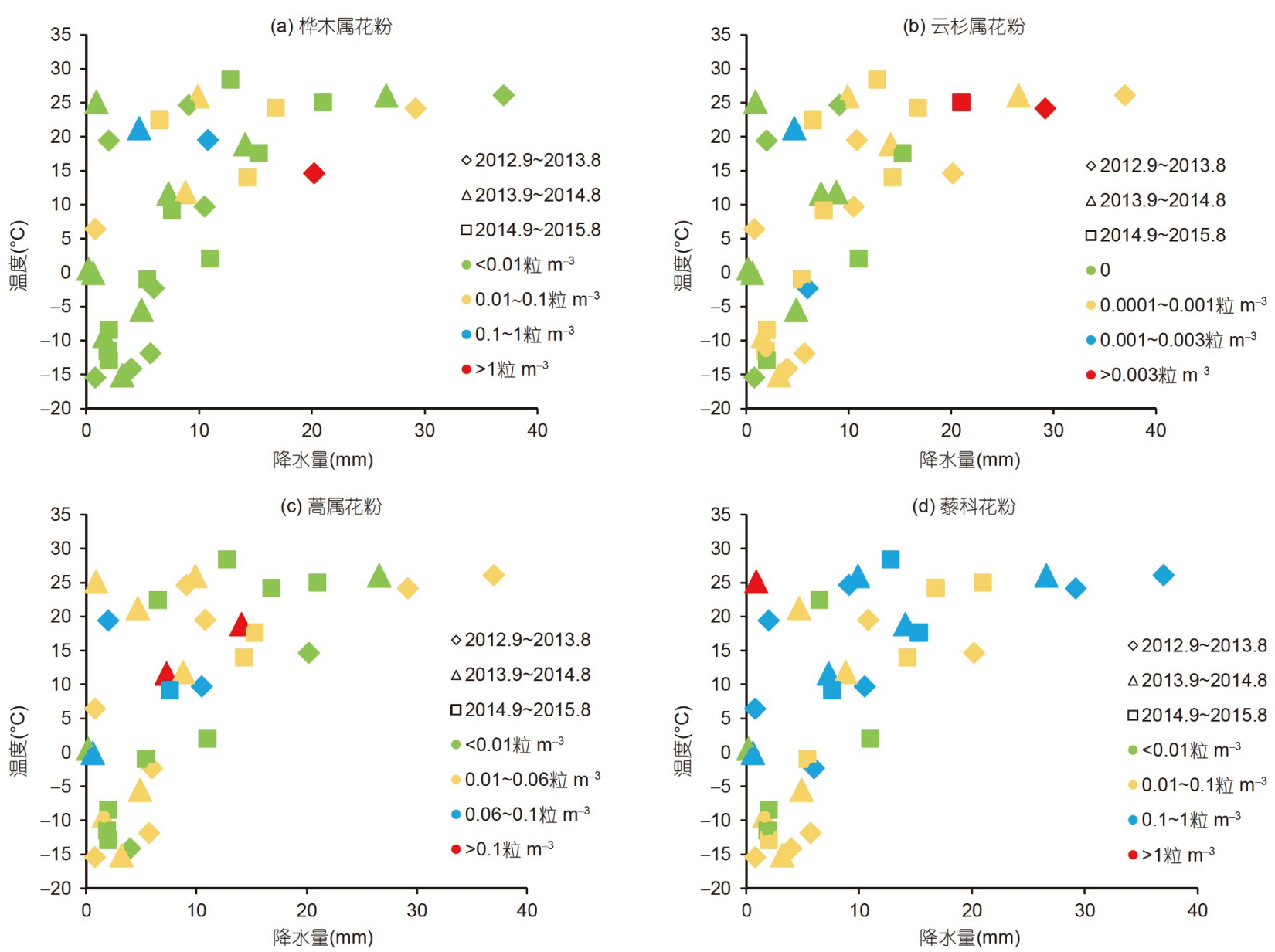

图 8 主要花粉类型的浓度与温度及降水的关系

含量, 并且过高的风速也会对花粉在空气中的传播和 收集有负面影响(刘克利等, 2009; 张雨辰等, 2018). 这 一年春季的温度相对较高, 而降水偏低, 不利于花期时 桦木属花粉的散布; 且春季时外来气流多来自研究区 东南部的准噶尔盆地(图6c)，几乎不携带乔木植物花 粉. 夏秋季时温度与其余两年相比较低，而降水和风 速偏高，这种环境不利于旱生植物如藜科和蒿属花粉 的散布. 莍科植物的花期一般在夏季，在秋季有少数 小高峰出现，但该年高风速(月均值高于 $2.5 \mathrm{~m} \mathrm{~s}^{-1}$ ) 持续 了整个春夏季，导致夏季时藜科和蒿属花粉浓度低于 秋季. 风速在该年秋季相对适中，且有来自西天山南 坡荒漠带的旱生植物花粉(图6i), 使得花粉浓度高峰出 现在当年秋季．尽管夏末有来自哈萨克丘陵的外来气 流，但因不处于乔木植物花期，未携带许多乔木植物 花粉；外来的蒿属和藜科花粉也较少，因哈萨克丘陵
不属于荒漠地带，这也是导致这一年的总花粉浓度最 低的可能原因.

\section{3 艾比湖小叶桦湿地中桦木属花粉的代表性}

作为新疆地区的珍稀自然物种，小叶桦具抗旱、 抗涝、抗盐的特点, 在干旱-半干旱地区的生态系统中 扮演着重要的角色. 因此, 找到影响艾比湖濒危树种小 叶桦分布的因素比较紧迫(Zhang和Kong，2019). 而在 古植被重建过程中, 桦木属花粉的代表性仍存在争议.

本研究通过对比小叶桦分布区和非小叶桦分布区 的表土花粉组合和大气花粉组合，探讨桦木属花粉的 代表性. 2012年9月到2015年8月中，艾比湖小叶桦湿 地的空气花粉组合中，桦木属花粉的占比为 $3.14 \sim 36.83 \%$ ，并且小叶华林中桦木的植被盖度超过 70\%．2001年7月到2006年7月天山中部非小叶桦分布 
区收集的114个大气花粉样品中, 桦木植被盖度却不到 $8.1 \%$ 的天池地区的桦木属花粉浓度均值仅 0.49 粒 $100 \mathrm{~m}^{-3}$ (李媛媛等, 2019), 位于荒漠地带的阜康和北沙 窝地区则以灌木植物库尔勒沙拐苯(Calligonum kuerlense)和梭梭(Haloxylon ammodendron)为主, 桦木属花 粉浓度均值仅 0.22 粒 $100 \mathrm{~m}^{-3}$, 百分比分别为 $0.10 \sim 0.71 \%$ 和0.10 0.42\%(李媛媛等，2019). 在新疆艾 比湖东大桥、喀纳斯一道湾以及石河子市的蘑菇湖等 小叶桦分布区所采集的表土花粉样品中以桦木属花粉 为主，百分比值多超过 $20 \%$ (最高达91\%)(王力，2019), 而在非桦木分布区，表土样品中的桦木属花粉占比很 低，不超过5\%(蔡遥等，2010；李媛媛等，2019; 王力， 2019). 因此，在非桦木分布区的表土和大气花粉样品 中，桦木属花粉的含量极低 $(<5 \%)$. 而在艾比湖小叶桦 湿地中，可认为桦木属花粉具较好的代表性并能够指 示当地桦木林的存在, 这与刘会平等(2001)和王力 (2019)的研究结果一致.

孢粉与植被间的关系是利用地层狍粉数据揭开和 重建古植被、古气候“真面目”的关键. 桦木属花粉在 本研究区具较好的代表性并可指示母体植物生长，该 结论可提高利用孢粉数据进行过去植被和气候环境重 建的精确度和可靠性.

\section{5 结论}

2012年9月到2015年8月在新疆艾比湖小叶桦湿地 收集的空气花粉样品中, 主要花粉类型以桦木属花粉 为主，还包括外来的花粉类型如云杉属、僽科以及蒿 属花粉，与局地植被分布较吻合，并且桦木属花粉在 花期时占比最高，可达 $90 \%$ 以上，均值也超出 $20 \%$. 气 象数据与大气花粉数据的分析表明, 大气花粉的季节 散布特征主要受到气象因子如温度、降水、风速和风 向的影响. 艾比湖湿地的大气花粉总浓度三年来(2012 年9月至2015年8月)的变化趋势为先增加后减少; 基于 HYSPLIT模型，在2012年9月至2013年8月，由外来气 流携自天山的云杉属花粉是致使该年乔木植物花粉浓 度达三年中最高值的原因之一; 在第二年的夏秋季 (2013年9月到2014年8月)，大量源自艾比湖湿地东南 部和中亚荒漠地区的外来草本植物花粉使得该年总花 粉浓度达三年最高; 在2014年9月到2015年8月中总花 粉浓度处于三年中的最低值, 应与秋末时来自哈萨克
丘陵的气流携带外来草本植物花粉量较少有关.

通过对比新疆地区表土和大气花粉样品, 特别是 在桦木分布区和非桦木分布区中，桦木属花粉对现代 植被有较好的指示意义, 能够反映当地植物群落的分 布. 作为艾比湖湿地的指示种，本研究可为桦木属花 粉在大气中的散布特征提供可靠的资料, 并为狍粉-植 被-气候模型以及古植被重建工作提供基础数据.

致谢空气花粉样品由艾比湖国家湿地自然保护区的高 言和保尔达收集, 部分数据由浙江师范大学倪健教授提 供, 一并致谢. 感谢中国气象数据网(http://data.cma.cn)和 国家科技基础条件平台-国家地球系统科学数据中心 (http://www.geodata.cn)提供数据支撑.

\section{参考文献}

蔡新斌, 买尔燕古丽·阿不都热合曼, 江晓珩, 林宣龙, 田润炜, 布早拉 木. 2015. 新疆湿地资源时空变化特征及其原因分析研究. 气候 变化研究进展, 11: 395-401

蔡遥, 王燕, 蒋复初, 李朝柱. 2010. 川北若尔盖高原表土狍粉的特征 及其与现代植被的关系. 地质通报, 29: 707-712

戴璐, 翁成郁. 2010. 西太平洋海域冬季花粉传播观测及其在东亚季 风研究中的意义. 中国科学: 地球科学, 40: 893-902

方伊曼. 2015. 南京仙林地区大气花粉传播规律及其与气象要素的 关系研究. 硕士学位论文. 南京: 南京大学

何海娟, 张德山, 乔秉善. 2001. 北京城区空气中花粉含量与气象要 素的关系初探. 中华微生物学和免疫学杂志, 21: 31-33

蒋素雪. 2010. 兰州地区空气孢粉组合特征及特殊天气的影响. 硕士 学位论文. 石家庄: 河北师范大学

李英, 李月丛, 吕素青, 许清海. 2014. 石家庄市空气花粉散布规律及 与气候因子的关系. 生态学报, 34: 1575-1586

李玉梅. 2019. 新疆北部典型湿地4700年以来环境和植被演变研究. 博士学位论文. 长春: 吉林大学

李媛媛, 张芸, 倪健, 孔昭宸, 王力, 李玉梅, 陈立欣. 2019. 新疆天山 大气桦木花粉与气象因子的相关分析. 科学通报, 64: 1909-1921 刘会平, 唐晓春, 王开发, 潘安定. 2001. 神农架北坡表土常见花粉的 $\mathrm{R}$ 值研究. 地理科学, 21: 378-380

刘克利, 孙红斌, 王旭东, 冯震. 2009. 呼和浩特市花粉浓度与气象因 子关系的分析. 内蒙古气象, 6: 22-24

吕素青, 李月丛, 许清海, 李英, 刘耀亮, 梁剑. 2012. 陕西中部黄土高 原地区空气花粉组成及其与气候因子的关系一以洛川县下黑 木沟村为例. 生态学报, 32: 7654-7666

毛利米. 2008. 新疆天山中段北部空中花粉数量的时空变化及其气 候与植被指示意义. 博士后研究工作报告. 北京: 中国科学院植 
物研究所

潘燕芳, 阎顺, 穆桂金, 孔昭宸, 倪健, 杨振京. 2011. 天山雪岭云杉大

气花粉含量对气温变化的响应. 生态学报, 31: 6999-7006

桑艳礼, 马玉贞, 高尚玉, 伍婧, 蒙红卫, 孙爱芝, 满自红. 2008. 甘肃 兴隆山国家自然保护区表土花粉组合及数量分析. 古生物学报, 47: $457-467$

田润炜, 李光明, 蔡新斌, 买尔燕古丽·阿不都热合曼, 江晓街, 刘丽 燕, 林宣龙, 布早拉木·吐尔逊. 2017. 2001年与2011年新疆南疆和 北疆湿地景观格局比较. 湿地科学, 15: 358-363

王力. 2019. 全新世新疆北部小叶桦湿地植被演变及环境因素分析. 硕士学位论文. 北京: 中国科学院植物研究所

徐家声. 1994. 黄海大气中的狍粉及其对海底沉积物中孢粉组合的 影响. 植物学报, 36: 720-726

许英勤, 阎顺, 贾宝全, 杨云良. 1996. 天山南坡表土孢粉分析及其与 植被的数量关系. 干旱区地理, 19: 24-30

张军, 徐新, 张增信, 张强, 问少峰. 2009. 南京市空气中花粉特征及 其与气象条件关系. 气象与环境学报, 25: 67-71

张雨辰, 马春梅, 方伊曼. 2018. 大气花粉监测与传播研究进展. 微体 古生物学报, 35: 200-210

赵楠楠, 杨振京, 宁凯, 杨庆华, 张茹春. 2019. 依连哈比尔尔山南北 坡表土孢粉与植被关系研究. 干旱区资源与环境, 33: 117-126

Bao A M, Mu G J, Zhang Y, Feng X W, Chang C, Yin X J. 2006. Estimation of the rational water area for controlling wind erosion in the dried-up basin of the Ebinur Lake and its effect detection. Chin Sci Bull, 51: 68-74

Bortenschlager S, Bortenschlager I. 2005. Altering airborne pollen concentrations due to the Global Warming. A comparative analysis of airborne pollen records from Innsbruck and Obergurgl (Austria) for the period 1980-2001. Grana, 44: 172-180

Caramiello R, Siniscalco C, Mercalli L, Potenza A. 1994. The relationship between airborne pollen grains and unusual weather conditions in Turin (Italy) in 1989, 1990 and 1991. Grana, 33: 327332

Cariñanos P, Galan C, Alcázar P, Domınguez E. 2004. Airborne pollen records response to climatic conditions in arid areas of the Iberian Peninsula. Environ Exp Bot, 52: 11-22

Celenk S. 2019. Detection of reactive allergens in long-distance transported pollen grains: Evidence from Ambrosia. Atmos Environ, 209: $212-219$

Crimi P, Macrina G, Folli C, Bertoluzzo L, Brichetto L, Caviglia I, Fiorina A. 2004. Correlation between meteorological conditions and Parietaria pollen concentration in Alassio, north-west Italy. Int J Biometeorol, 49: 13-17

Cour P. 1974. Nouvelles techniques de detection des flux et des retombees polliniques: Etude de la sedimentation des pollens et des spores a la surface du sol. Pollen Spores, 16: 103-141
Darrah S E, Shennan-Farpón Y, Loh J, Davidson N C, Finlayson C M, Gardner R C, Walpole M J. 2019. Improvements to the Wetland Extent Trends (WET) index as a tool for monitoring natural and human-made wetlands. Ecol Indic, 99: 294-298

Dimitriou K, Kassomenos P. 2014. A study on the reconstitution of daily $\mathrm{PM}_{10}$ and $\mathrm{PM}_{2.5}$ levels in Paris with a multivariate linear regression model. Atmos Environ, 98: 648-654

Draxler R R, Hess G D. 1998. An overview of the HYSPLIT_4 modelling system for trajectories. Aust Met Mag, 47: 295-308

Erwin K L. 2009. Wetlands and global climate change: The role of wetland restoration in a changing world. Wetlands Ecol Manage, 17: $71-84$

Fang Y M, Ma C M, Bunting M J, Ding A J, Lu H Y, Sun W F. 2018. Airborne pollen concentration in Nanjing, Eastern China, and its relationship with meteorological factors. J Geophys Res-Atmos, 123: 10,842

Jato V, Dopazo A, Aira M J. 2002. Influence of precipitation and temperature on airborne pollen concentration in Santiago de Compostela (Spain). Grana, 41: 232-241

Latorre F. 1999. Differences between airborne pollen and flowering phenology of urban trees with reference to production, dispersal and interannual climate variability. Aerobiologia, 15: 131-141

Lu X M, Herrmann M, Mosbrugger V, Yao T D, Zhu L P. 2010. Airborne pollen in the Nam Co Basin and its implication for palaeoenvironmental reconstruction. Rev Palaeobot Palynol, 163: 104-112

Lü X, Paudayal K N, Uhl D, Zhu L, Yao T, Mosbrugger V. 2020. Phenology and climatic regime inferred from airborne pollen on the northern slope of the Qomolangma (Everest) region. J Geophys ResAtmos, 125: e33405

Luo C X, Jiang W M, Chen C X, Peng H H, Xiang R, Liu J G, Lu J, Su X, Zhang Q, Yang M X. 2018. Modern pollen distribution in the northeastern Indian Ocean and its significance. Int J Biometeorol, 62: $1471-1488$

Mao D H, Luo L, Wang Z M, Wilson M C, Zeng Y, Wu B F, Wu J G. 2018. Conversions between natural wetlands and farmland in China: A multiscale geospatial analysis. Sci Total Environ, 634: 550-560

Meiffren I. 1988. Airborne pollen of Toulouse, southern France. Grana, 27: 183-201

Monroy-Colín A, Maya-Manzano J M, Tormo-Molina R, PeceroCasimiro R, Gonzalo-Garijo M Á, Fernández-Rodríguez S. 2020. HYSPLIT as an environmental impact assessment tool to study the data discrepancies between Olea europaea airborne pollen records and its phenology in SW Spain. Urban Forry Urban Greening, 53: 126715

Mu G, Yan S, Ji A, He Q, Xai X. 2002. Wind erosion at the dry-up 
bottom of Aiby Lake. Sci China Ser D-Earth Sci, 45: 157-164

Nagalingum N S, Drinnan A N, Lupia R, McLoughlin S. 2002. Fern spore diversity and abundance in Australia during the Cretaceous. Rev Palaeobot Palynol, 119: 69-92

Pasken R, Pietrowicz J A. 2005. Using dispersion and mesoscale meteorological models to forecast pollen concentrations. Atmos Environ, 39: 7689-7701

Plaza M P, Alcázar P, Hernández-Ceballos M A, Galán C. 2016. Mismatch in aeroallergens and airborne grass pollen concentrations. Atmos Environ, 144: 361-369

Rahman A, Luo C X, Chen B S, Haberle S, Khan M H R, Jiang W M, Xiang R, Liu J G, Wang L S, Lin G, Yang M X, Thilakanayaka V. 2019. Regional and seasonal variation of airborne pollen and spores among the cities of South China. Acta Ecol Sin, 40: 283-295

Ramsar Convention. 2018. Global Wetland Outlook: State of the World's Wetlands and Their Services to People. Switzerland: Ramsar Convention Secretariat

Ribeiro H, Santos L, Abreu I, Cunha M. 2006. Influence of meteorological parameters on Olea flowering date and airborne pollen concentration in four regions of Portugal. Grana, 45: 115-121

Rojo J, Rapp A, Lara B, Fernández-González F, Pérez-Badia R. 2015. Effect of land uses and wind direction on the contribution of local sources to airborne pollen. Sci Total Environ, 538: 672-682

Rolph G, Stein A, Stunder B. 2017. Real-time environmental applications and display system: READY. Environ Model Softw, 95: $210-228$

Rousseau D D, Schevin P, Duzer D, Cambon G, Ferrier J, Jolly D, Poulsen U. 2006. New evidence of long distance pollen transport to southern Greenland in late spring. Rev Palaeobot Palynol, 141: 277286

Sabit M, Ramos J D, Alejandro G J, Galan C. 2016. Seasonal distribution of airborne pollen in Manila, Philippines, and the effect of meteorological factors to its daily concentrations. Aerobiologia, 32: $375-383$

Spieksma F T M, Emberlin J C, Hjelmroos M, Jäger S, Leuschner R M. 1995. Atmospheric birch (Betula) pollen in Europe: Trends and fluctuations in annual quantities and the starting dates of the seasons. Grana, 34: 51-57

Stein A F, Draxler R R, Rolph G D, Stunder B J B, Cohen M D, Ngan F. 2015. NOAA's HYSPLIT atmospheric transport and dispersion modeling system. Bull Am Meteorol Soc, 96: 2059-2077
Stępalska D, Myszkowska D, Piotrowicz K, Kluska K, Chłopek K, Grewling Ł, Lafférsová J, Majkowska-Wojciechowska B, Malkiewicz M, Piotrowska-Weryszko K, Puc M, Rodinkova V, Rybníček O, Ščevková J, Voloshchuk K. 2020. High Ambrosia pollen concentrations in Poland respecting the long distance transport (LDT). Sci Total Environ, 736: 139615

Stjepanović B, Svečnjak Z, Hrga I, Večenaj A, Šćepanović M, Barić K. 2015. Seasonal variation of airborne ragweed (Ambrosia artemisiifolia L.) pollen in Zagreb, Croatia. Aerobiologia, 31: 525-535

Stohl A. 1988. Computation, accuracy and applications of trajectoriesA review and bibliography. Atmos Environ, 32: 947-966

Tang L Y, Mao L M, Lü X M, Ma Q F, Zhou Z Z, Yang C L, Kong Z C, Batten D J. 2013. Palaeoecological and palaeoenvironmental significance of some important spores and micro-algae in Quaternary deposits. Chin Sci Bull, 58: 3125-3139

Wang J Z, Ding J L, Li G N, Liang J, Yu D L, Aishan T, Zhang F, Yang J M, Abulimiti A, Liu J. 2019. Dynamic detection of water surface area of Ebinur Lake using multi-source satellite data (Landsat and Sentinel-1A) and its responses to changing environment. Catena, 177: 189-201

Xu J X, Zhang D S, Li L H. 2012. Seasonal variations of airborne pollen in Beijing, China and their relationships with meteorological factors. Acta Ecol Sin, 32: 202-208

Zhang S, Xu Q, Gaillard M J, Cao X, Li J, Zhang L, Li Y, Tian F, Zhou L, Lin F, Yang X. 2016. Characteristic pollen source area and vertical pollen dispersal and deposition in a mixed coniferous and deciduous broad-leaved woodland in the Changbai mountains, northeast China. Veget Hist Archaeobot, 25: 29-43

Zhang Y, Kong Z C. 2019. Changes in wetland salinity, human activity and wetland vegetation abundances over the past 900 years. Glob Planet Change, 182: 103000

Zhang Y, Kong Z C, Wang G H, Ni J. 2010. Anthropogenic and climatic impacts on surface pollen assemblages along a precipitation gradient in north-eastern China. Glob Ecol Biogeogr, 19: 621-631

Zhao K, Zhou X, Ji M, Li X. 2019. Palynological evidence of late Holocene paleo-monsoon in eastern Pamir. Geophys Res Lett, 46: 10015-10023

Zhao Y, Miao Y, Fang Y, Li Y, Lei Y, Chen X, Dong W, An C. 2021. Investigation of factors affecting surface pollen assemblages in the Balikun Basin, central Asia: Implications for palaeoenvironmental reconstructions. Ecol Indic, 123: 107332

(责任编委: 赵艳) 